small portion of the crops bas been destroyed by sand and mud, but nothing like the amount that was supposed at first. Here every house and structure that was built of stone was simply shaken to pieces; but the buildings were never intended to stand earthquakes, and when one sees the kind of structures they are, great shapeless lumps of stone laid in very inferior mortar, one is not surprised that they all came down, though it is doubtful whether the best of masonry would have stood the shock. In the cemetery huge slabs of granite or marble have been jerked several inches out of their places. It has been most interesting work investigating the results of the shock. I have not yet heard what opinion my colleagues, who have gone out in various directions to make observations, have formed about the cause of the shocks; but my own opinion is that they are due to movement along a line of fault running along the southern side of the Khasia and Garo Hills, from near Cachar on the east to and beyond the Bramahputra. If you look at the map of Assam you will see that the southern boundary of these hills is a very straight line. The rocks are bent down suddenly along this line in a uniclinal curve, and to the south of it the plains of Sylhet and Lower Bengal are certainly a region of subsidence. If I should prove to be right, it will be a most interesting case of earth-movement on a large scale. I believe also that the 'Barisal guns,' which have been a puzzle for so many years, are connected with the same movement, and are caused by slight slips, not sufficient to cause actual shocks of earthquake. The sounds one hears here, sometimes accompanied or followed by a shock, but sometimes also without any shock, are exceedingly like the 'guns.'

"At the beginning of the week I put up here a roughly constructed seismograph for observing the shocks, which still con tinue, though they are gradually getting less violent and less frequent than at first. The instrument is in principle, I believe, due to Prof. Ewing, of Tokio, and gives a trace of the horizontal movement of a point on the surface of the earth on a piece of smoked glass. From this it is easy to take prints on a piece of sensitised paper, and I send you some of the results [one of the prints is here repro. duced] I have already obtained. The trace is mag. nified 6.7 times by the instrument, so that one can form an idea from it of how exceedingly minute the actual movement of the surface is, and yet the two taken in

the morning of the Igth were fairly severe shocks. The first, at I. 39 a.m., was a very sudden bump, and was soon over; but the other, at $6.50 \mathrm{a} . \mathrm{m}$., lasted some fifteen to twenty seconds. This instrument cost altogether about $6 d$. to put up; I am making another rather more carefully, which will be looked after by the Public Works Engineer here when I leave.

"The house I used to live in is perfectly flat on the ground. It is wonderful that so few people were killed; but the first shock came at a time of day when most people were out of doors, and only two Europeans were killed and about ten natives, who were all in the Government Press building, the only house of more than one story in the place. If it had happened at night, or at the same time next day, when many of the people would have been at church, there would have been great loss of life. I am going on from here to Cherrapungi, where the damage has been very great, chiefly caused by landslips, and then back to Calcutta through Sylhet."

\section{The Centipede-Whale.}

I AM very much desirous of being informed by you, or some of your readers, what animal is meant by "Scolopendra Cetacea," which, according to Johnston, has only been described by Ælian: "Scolopendrae vim et naturam, ... quoddam etiam maximame cêtos marinum eam esse audivi, quam de mari tempestatibus in litus expulsam nemo foret tam audax, quin aspicere horreret. Ii verò qui res maritimas percallent, eas inquiunt toto capite spectari eminentes è mari : et narium pilos magna excelsitate

$$
\text { NO. } 1454 \text {, VOL. } 56]
$$

apparere, et ejus caudam similiter atque locustae latam perspici : reliquum etiam corpus aliquando in superficie aequoris spectari, idque conferri posse cum triremi instae magnitudinis, atque permultis pedibus utrinque ordine sitis, tanquam ex scalmis appensis, natare. Addunt harum rerum periti ac fide digni, ipsos etiam fluctus ea natante leviter subsonare." ("De Natura Animalium," lib. xiii. cap. 23.) In Gesner's " Historia Animalium," lib. iv., Francfort, 1604 , p. 838 , a figure is given of this animal said to have been seen in India.

That the Japanese of old had some notion of such an animal is well shown in Kaibara's "Yamato Honzô" ( 1708 , tom. xiii. f. 4r, b.), where it is said: "The Mukade-Kujira [=CentipedeWhale] is as large as a whale, and has five fins on the back and a two-cleft tail. Its legs number twelve, six being on each side its flesh is coloured red and very venomous, man being killed when he eats it."

Here I may add that Olaus Magnus's "Cetus Barbatus," which is assimilated with the "Scolopendra Cetacea" in the book of Gesner (ut supr., and figured on p. 207), appears to be but an exaggerated portrait of some huge Cephalopod; and also that I was lately told by Captain Miura, of the Fuji, of his having experienced a serious illness in consequence of eating flesh of a gigantic cuttlefish in the Pacific Ocean.

Kumagusu Minakata.

I 5 Blithfield Street, Kensington, W., August 30.

\section{THE APPROACHING TOTAL ECLIPSE OF THE SUN. ${ }^{1}$}

VI.

I $\mathrm{N}$ the third article under the above heading, when referring to the suggested programme for the observations of the next eclipse, I stated briefly the divergent views held with regard to the true locus of origin of the absorption which produces the Fraunhofer lines. It is, I think, worth while to return to this subject in order that the results obtained from the double series of photographs obtained during the eclipse of 1893 may be indicated. I pointed out that in the photographs in question the radiation spectrum was most distinctly not identical with the Fraunhofer spectrum; the most important point being that some of the strongest bright lines do not appear among the dark ones in the solar spectrum, while some of the strongest dark lines are not seen bright in the spectrum of the stratum of vapours in immediate contact with the photosphere. The region covered by the diagram, given in my paper in the Phil. Trans., lies between wave-lengths 4 I00 and 4300 , but similar results follow when other regions are included in the inquiry.

These positive conclusions are not weakened by the consideration that the resolving power of the prismatic cameras employed in 1893 is not sufficiently great to show all the lines of the Fraunhofer spectrum, which is used as a term of comparison; in fact, working under exactly the same conditions as during the eclipse, the instrument employed in Africa only shows IO4 lines in the spectra of stars resembling the sun, in the region $h$ to $\mathrm{H}$, in place of 940 given in Rowland's tables of lines in the solar spectrum. We, therefore, get a better term of comparison if we employ the spectrum of some star such as Arcturus, which closely resembles the sun. Such a comparison is shown in Fig. 24 ; out of 104 lines which the instrument is capable of depicting in the region $h$ to $\mathrm{H}$, only 40 are shown in the spectrum of the base of the sun's atmosphere. This comparison amply confirms the conclusion that the lines reversed at the beginning or end of totality, though fairly numerous, do not correspond in intensity, though some of them correspond in position with the dark lines of the solar spectrum, and consequently that the so-called "reversing layer" close to the photosphere is incompetent to produce, by its absorption, the Fraunhofer lines. Further, as previously pointed out, while the chromosphere fails to show most of the lines 